\title{
FUNKCJONOWANIE ORGANIZACJI INTELIGENTNEJ NA PRZYKŁADZIE MIKROPRZEDSIĘBIORSTWA „B+R STUDIO ANALIZY RYNKU MEBLARSKIEGO”
}

\author{
Anna Rumocka \\ Politechnika Częstochowska \\ Wydział Zarządzania
}

\begin{abstract}
Streszczenie: W artykule na przykładzie mikroprzedsiębiorstwa „B+R Studio Analizy Rynku Meblarskiego" przedstawiono funkcjonowanie organizacji inteligentnej, które w swojej codziennej praktyce nie tylko rozumie pojęcia kapitału intelektualnego i zarządzania wiedzą, ale realizuje strategie zarządzania wiedzą. Firma prowadzi bezpłatną usługę - Komentarz Meblarski, w ramach której zespół pracowników firmy dzieli się z odbiorcami zewnętrznymi wiedzą wewnętrzną, zarezerwowaną dotychczas jako ukryta. Komentarz Meblarski skierowany jest do branży meblarskiej i obszarów powiązanych, które aby podejmować skuteczne decyzje, powinny mieć dostęp do wiedzy i aktualnych źródeł informacji. Celem artykułu jest próba odpowiedzi, czy mikroprzedsiębiorstwa mogą skutecznie rozwijać się jako organizacje inteligentne.
\end{abstract}

Słowa kluczowe: organizacja inteligentna, mikroprzedsiębiorstwo, transfer wiedzy, kapitał intelektualny, rodzaje wiedzy

DOI: $10.17512 /$ znpcz.2016.3.1.17

\section{Charakterystyka organizacji inteligentnej}

Organizacje inteligentne to temat często poruszany przez teoretyków, jak i praktyków. W publikacjach charakterystyka organizacji inteligentnej przedstawiana jest najczęściej na przykładzie średnich przedsiębiorstw. Tymczasem organizacjami inteligentnymi są również mikro i małe przedsiębiorstwa, które nie tylko rozumieją istotę systemu zarządzania wiedzą i organizacji inteligentnej, ale skutecznie ją realizują poprzez codzienną praktykę gospodarczą i działalność rynkową, co m.in. przejawia się $\mathrm{w}$ trwałej współpracy z partnerami krajowymi i zagranicznymi. To dzięki wdrażaniu i realizowaniu idei organizacji inteligentnej krajowe przedsiębiorstwa, te najmniejszej wielkości, mogą się rozwijać. Zawdzięczać to należy m.in. coraz lepszej komunikacji, wykorzystaniu Internetu, kreatywnemu działaniu i podejmowanemu procesowi twórczemu, kompetencji pracowników i partnerów, jak również nieustannemu uczeniu się. Wynikiem tej ciągłej pracy, jak w przypadku opisywanego mikroprzedsiębiorstwa, jest efektywniejsze sprostanie wymogom rynku, wyzwaniom stawianym przez gospodarkę poprzez skuteczniejszy proces twórczy, przeobrażanie usług i adaptację do przyszłych wymagań klientów. Te działania pozwalają na dotarcie do niezbędnych 
informacji i wykorzystanie ich $\mathrm{w}$ realizowaniu strategii zarządzania wiedzą. Podstawowe strategie zarządzania wiedzą zaprezentowane zostały w Tabeli 1 .

Tabela 1. Cztery podstawowe strategie zarządzania wiedzą

\begin{tabular}{|c|c|}
\hline Typy strategii & Charakterystyka \\
\hline $\begin{array}{l}\text { Kreacja wiedzy przez } \\
\text { współdziałanie }\end{array}$ & $\begin{array}{l}\text { Aktywna współpraca } \mathrm{z} \text { instytucjami zewnętrznymi i prowa- } \\
\text { dzenie prac badawczych w celu stworzenia wiedzy nowej, } \\
\text { innowacyjnej. Ewentualny zakup wiedzy wytworzonej } \\
\text { w instytucjach B+R }\end{array}$ \\
\hline Kreacja wewnętrzna & $\begin{array}{l}\text { Prowadzenie procesów kreowania wiedzy wewnątrz } \\
\text { organizacji mających na celu wytworzenie nowej wiedzy lub } \\
\text { uzyskanie nowej jakości wiedzy, którą organizacja posiadła } \\
\text { poprzez absorpcję lub kreację przez współdziałanie. } \\
\text { Podstawową jednostką tworzenia wiedzy jest zespół. }\end{array}$ \\
\hline Absorpcja & $\begin{array}{l}\text { Ma na celu pozyskanie nowej wiedzy, istniejącej w otocze- } \\
\text { niu poprzez jej transfer } \mathrm{z} \text { wykorzystaniem odpowiednio } \\
\text { dobranych metod. }\end{array}$ \\
\hline $\begin{array}{l}\text { Rozpowszechnianie } \\
\text { wewnątrz }\end{array}$ & $\begin{array}{l}\text { Koncentruje się na transferze wiedzy wewnątrz organizacji, } \\
\text { między jej różnymi obszarami działalności i częściami. } \\
\text { Podstawą jej prowadzenia jest sieć między ludźmi } \\
\text { umożliwiająca przepływy wiedzy oraz system rejestracji } \\
\text { wiedzy. }\end{array}$ \\
\hline
\end{tabular}

Źródło: (Mikuła 2005, s. 31)

Istotę organizacji inteligentnej należy rozumieć jako system, który korzysta ze zbiorowej inteligencji. Jako bezwzględnie nadrzędne cechy tej organizacji, czy też zasadnicze umiejętności praktyczne, implementowane przez mikroorganizacje inteligentne, należy podać m.in.:

- animowanie i kreowanie nowych rynków, tworzenie nisz (powodujące specjalizację, mistrzostwo, organizację zatrudniających ekspertów i korzystających ze współpracy z ekspertami, np. outsourcing);

- inspirowanie nowych potrzeb potencjalnych klientów, zarówno biznesowych, jak i indywidualnych, stymulowanie popytu.

\section{Cechy mikroprzedsiębiorstw}

Mikroprzedsiębiorstwa definiuje się jako przedsiębiorstwa zatrudniające mniej niż dziesięciu pracowników, których roczne obroty oraz/lub całkowity bilans roczny nie przekracza 2 mln EUR (Nowa definicja MŚP 2006, s. 14). Często powtarzanym poglądem jest ten, że mikroprzedsiębiorstwa są bardziej elastyczne, co sprzyja ich rozwojowi i szybszej reakcji na sytuację rynkową. Ważną cechą mikroprzedsiębiorstwa są również wysokie zdolności adaptacyjne, co w świecie dynamicznych zmian jest pożądane od każdej firmy, która chce sprostać wymaganiom i usatysfakcjonować klienta, nabywcę. Tego rodzaju podmioty mogą się rozwijać oraz wykorzystywać i stale poszerzać wiedzę, dzięki rozwojowi 
licznych kanałów komunikacji, które za sprawą multimediów, Internetu, właściwej konwergencji zjawisk i działów mogą pozwolić na zdobywanie zarówno klientów, jak i partnerów, w ujęciu globalnym.

Mikroprzedsiębiorstwa napotykają wiele przeciwności w swoim codziennym działaniu, a tą, która zdecydowanie ogranicza ich rozwój, są zasoby finansowe. Ograniczoność tychże zasobów pośrednio wpływa na poszukiwanie i wykorzystanie tańszych instrumentów, charakteryzujących się kreatywnością i nowatorskimi rozwiązaniami, które mogą przyczynić się do pozyskania partnerów zewnętrznych i sfinansowania wymagających inwestycji. W tym miejscu należy dodać, że wartości niematerialne - wiedza, intelekt - są kluczowe dla rozwoju organizacji, a już szczególnie organizacji inteligentnej. Mikroprzedsiębiorstwa są zmuszone do poszukiwania innych instrumentów uzyskiwania przewagi konkurencyjnej w obszarach:

1. polityki personalnej,

2. zarządzania wiedzą,

3. zarządzania kapitałem intelektualnym (Stosik 2005, s. 178).

Mikroprzedsiębiorstwa ukierunkowane na rozwój i umacnianie swojej pozycji na rynku powinny umieć sprostać wymaganiom nowoczesnej gospodarki, gospodarki opartej na wiedzy. Co nie ogranicza się tylko do posiadania atrybutów charakterystycznych dla nowoczesnej organizacji, ale funkcjonalnego ich wykorzystania. Na Rysunku 1 przedstawiono atrybuty organizacji nowego typu, organizacji inteligentnych, które są otwarte i skłonne do innowacyjnych realizacji własnych projektów i skutecznego wykorzystania zarządzania wiedzą oraz posługiwania się kapitałem intelektualnym.

Zasadnicze atrybuty nowej organizacji

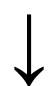

- liczy się to, co organizacja wie i potrafi, a nie stan jej posiadania

- organizacja gromadzi potencjał wiedzy

- budowanie przewagi strategicznej na podstawie unikalnych kompetencji

- zmiana jest permanentna

- przechodzenie od funkcji do procesów

- odejście od hierarchii na rzecz relacji

- spłaszczenie struktur organizacyjnych

- upowszechnienie pracy zespołowej

- pozyskiwanie i utrzymywanie pracowników o wysokim potencjale intelektualnym

- komunikacja wspomagana technologiami informatycznymi

Rysunek 1. Atrybuty organizacji nowego typu

Źródło: (Morawski 2005, s. 100) 


\section{Wiedza ukryta i kapitał intelektualny w dzialalności mikroprzedsiębiorstw}

Zarządzanie wiedzą i kapitałem intelektualnym to kwestie, którymi przedsiębiorstwa małe i mikro coraz częściej się interesują. W przypadku ograniczeń zasobów finansowych środki te coraz częściej zamiast przeznaczenia na reklamę i promocję, czy też szerzej na działania marketingowe, są wykorzystywane na pozyskiwanie użytecznych zasobów informacji, przetwarzanie ich i w efekcie dzielenie się wiedzą ukrytą. To właśnie ten rodzaj aktywności pozwala na wyróżnienie na rynku, podkreślenie swojej unikatowości. Potencjalni nabywcy otrzymują wiedzę, która do tej pory nie była dla nich osiągalna. Jednak przy tego rodzaju działaniach nacisk należy położyć na sprawną i przemyślaną komunikację. Wiedzę ukrytą warto kierować wyłącznie do tych podmiotów, które traktowane są jako potencjalni klienci i partnerzy. Dzielenie się wiedzą ukrytą może pozwolić przyszłym nabywcom m.in. podjąć właściwe decyzje dotyczące zarządzania, zaplanować rozwój i ekspansję swej firmy. Takie przekazywanie wiedzy może przyczynić się do nawiązania stałych relacji biznesowych $\mathrm{z}$ firmą dysponującą unikatową wiedzą. Globalna gospodarka nie tylko zachęca, ale wręcz narzuca wyróżnienie organizacji na nasyconym rynku, gdzie dominuje nadprodukcja, szum informacyjny, przez jej unikatowość. Niezaprzeczalnie sposobem na tę unikatowość jest dzielenie się wiedzą ukrytą, dzięki kapitałowi intelektualnemu, który dane przedsiębiorstwo posiada.

Przywołane mikroprzedsiębiorstwo to przykład organizacji inteligentnej. Dlatego też swoim klientom, zarówno tym obecnym, jak i potencjalnym, proponuje wiedzę, która w znaczący sposób może przyczynić się do ich ekspansji, umocnienia pozycji, czy też stworzenia nowej oferty.

„B+R Studio”, wprowadzając bezpłatną usługę - Komentarz Meblarski, dzieli się wiedzą, która może wpływać na skuteczne działania adresatów Komentarza. Sygnalizuje kierunki rozwoju rynku meblarskiego. Prognozuje i analizuje nadchodzące trendy i potrzeby klientów firm branży meblarskiej. Wiedza ukryta, którą przedsiębiorstwo postanowiło się dzielić, ma dwojaki charakter:

1. Po pierwsze, Komentarz Meblarski zawiera informacje dotyczące interpretacji najważniejszych wskaźników, trendów dla branży meblarskiej.

2. Po drugie, prezentuje wybrane wyniki badań własnych.

Komentarz Meblarski to usługa, która nie zawiera zbędnych treści. Do odbiorców tejże usługi napływają przecież każdego dnia całe pakiety informacji, często niezawierające żadnych konkretów, konkluzji z punktu widzenia sektora czy danej firmy. Powstaje szum informacyjny, w którym to pracownicy firm muszą znaleźć te informacje, które będą dla nich kluczowe. Stąd uruchomienie usługi Komentarz Meblarski „B+R Studio” poprzedzone zostało wywiadami telefonicznymi. Miały one na celu zdobycie wiedzy o optymalnym sposobie dostarczania Komentarza oraz przystępnej jego formie. Komentarz Meblarski dostarczany jest co tydzień drogą elektroniczną na wskazany przez firmę adres. 


\section{Strategia zarządzania wiedzą w mikroprzedsiębiorstwie}

„B+R Studio Analizy Rynku Meblarskiego” może być potraktowane jako przykład firmy, która swoją przewagę i reputację zawdzięcza wyłącznie zarządzaniu wiedzą i kapitałem intelektualnym. Te wartości mają największy wkład w budowanie jej pozycji i zdobywanie zaufania klientów oraz partnerów, którzy chętnie decydują się na udział w badaniach czy dzielą się swoimi opiniami. Firma, która została $\mathrm{w}$ artykule przywołana jako przykład mikroprzedsiębiorstwa inteligentnego, dowodzi, że wszystkie podmioty, które chcą się rozwijać, muszą się pozbyć rutyny i zaakceptować pracę projektową i zadaniową. Zmiana cywilizacyjna powoduje, że „w wyścigu konkurencyjnym na czoło wysuwają się przede wszystkim firmy inteligentne, zdolne do nowatorskich i szybkich przystosowań, firmy wirtualne i zwinne, a wśród umiejętności zarządzania zdecydowanie prym wiedzie umiejętność zarządzania wiedzą i umiejętność w zakresie gromadzenia kapitału intelektualnego" (Grudzewski, Hejduk 2002, s. 13).

Tego rodzaju działania umożliwiają również współpracę z ekspertami, których wiedza i doświadczenie pozwala na rozwój samej organizacji oraz nieprzerwanie efektywne działanie. Nie można byłoby rozpatrywać firmy „B+R Studio” jako organizacji inteligentnej, gdyby nie zrozumienie istoty kapitału intelektualnego, zarządzanie tymże kapitałem, które w konsekwencji przyczynia się do realizacji przyjętej strategii i osiągnięcia satysfakcjonującej pozycji firmy - eksperta. Mimo wielu instytucji branżowych wspomagających ten sektor, to dzięki konsekwentnie realizowanej strategii „B+R Studio Analizy Rynku Meblarskiego” staje się coraz bardziej uznanym i cenionym źródłem wiadomości o rynku meblarskim, dzięki bezpłatnej usłudze, jak w przypadku Komentarza Meblarskiego, która jest kanałem udostępniania wiedzy ukrytej zainteresowanym podmiotom. Zespołowi „B+R Studio Analizy Rynku Meblarskiego" powierzane są coraz bardziej wymagające projekty, gdyż nieprzerwanie daje dowód posiadanych kompetencji. Podmioty zewnętrzne zdobywają coraz większe zaufanie.

Firma, na podstawie której dokonywana jest analiza, może być potraktowana jako przykład organizacji inteligentnej, czyli takiej, w której ważne miejsce zajmuje transfer wiedzy, indywidualna kreacja wiedzy z zachowaniem współpracy z partnerami czy nabywcami. W przypadku transferu wiedzy należy mieć na myśli ten wewnątrz organizacji oraz na zewnątrz, poza nią.

Mikroprzedsiębiorstwo „B+R Studio Analizy Rynku Meblarskiego” to przykład organizacji inteligentnej, która rozumie i realizuje kwestie synergii. Nie jest ona wyłącznie pojmowana jako efekt zespołowej, wspólnej pracy zatrudnionych pracowników, ale również jako synergia zewnętrzna. Te dwa rodzaje synergii pozwalają na kompleksowe prowadzenie działań, a współpraca z podmiotami zewnętrznymi wyzwala nowe systemy współpracy w ramach synergii. Organizacja inteligentna sprzyja, tak jak w przypadku „B+R Studio Analizy Rynku Meblarskiego", rozwojowi różnych form pracy, np. pracy zdalnej. Jej uruchomienie $\mathrm{w}$ firmie zdecydowanie pozwala na pozyskanie do pracy specjalistów, którzy wspólnie pracują z zespołem projektowym nad konkretnym zadaniem. Jest to szczególnie istotne dla małego przedsiębiorstwa, które dzięki tej formie pracy 
i wykorzystaniu nowoczesnych form komunikacji może do współpracy pozyskać ekspertów.

Pracownicy rozumieją wyzwania stawiane przez rynek i chcą na nie odpowiadać, być aktualnym źródłem wiedzy dla firm z sektora meblarskiego, kształtować w ten sposób markę i dbać o reputację „B+R Studio Analizy Rynku Meblarskiego". Mikroprzedsiębiorstwo, o którym mowa w artykule, jeżeli chce odpowiadać na wyzwania, osiągać swoje cele i dążyć do sukcesu, ,[...] będzie musiało dostosować się do międzynarodowych standardów efektywności. Nastąpi dalsze zaostrzenie wszechobecnej i perfekcyjnej konkurencji, pod jej wpływem słabsze firmy będą szybciej znikać z rynku, gdyż w każdej branży trzeba będzie konkurować z najlepszymi na świecie" (Morawski 2005, s. 93). W przypadku tej firmy oznacza to dzielenie się i najbardziej optymalne wykorzystanie wiedzy ukrytej, której lokalizacją są ludzkie umysły. Usługa, jaką jest Komentarz Meblarski, mogła się powieść i rozwijać dzięki skuteczności realizacji działań operacyjnych. Do zadań operacyjnych należy zaliczyć: identyfikowanie, transfer (pozyskiwanie, udostępnianie, rozpowszechnianie, dzielenie się), kreowanie, gromadzenie, selekcjonowanie, łączenie, zapisywanie, przechowywanie (utrzymanie), ocenianie (badanie użyteczności), stosowanie wiedzy (Mikuła 2006, s. 40). Uwagę przywiązuje się zwłaszcza do gromadzenia wiedzy i jej kreowania oraz selekcjonowania. Te wyróżnione etapy pozwalają na tworzenie zasobów, które budują zaufanie odbiorców Komentarza Meblarskiego do firmy i przywołanej usługi.

\section{Gromadzenie wiedzy w mikroprzedsiębiorstwie}

Gromadzenie wiedzy w „B+R Studio Analizy Rynku Meblarskiego” jest rozumiane jako ,[...] proces systematycznego zbierania wiedzy (analogiczny do gromadzenia archiwów czy zbiorów bibliotecznych), będący efektem jej pozyskiwania lub wykreowania. W zależności od typu wiedzy na gromadzenie wiedzy mogą składać się różne czynności. Ludzie pozyskują lub tworzą wiedzę spersonalizowaną $\mathrm{i}$ gromadzą ją $\mathrm{w}$ umyśle, aby poddać ją następnie selekcji i ocenie. Gromadzenie wiedzy skodyfikowanej polega na zbieraniu informacji zawartych w notatkach, artykułach, książkach, różnych bazach danych, aby otrzymać użyteczny zbiór między innymi dla celów selekcji, zapisania i przechowywania. Gromadzone także mogą być zasoby wiedzy ugruntowanej, których nośnikiem są produkty konkurencji czy własne prototypy" (Mikuła 2006, s. 41). To podejście i wspólne akceptowanie wartości i definicji przynosi widoczne rezultaty.

\section{Kreowanie wiedzy w mikroprzedsiębiorstwie}

Kolejnym elementem, na który kładziony jest duży nacisk, jest wspomniane kreowanie wiedzy. W firmie została przyjęta definicja, która - jak określił Bogusz Mikuła - powinna być rozumiana jako ,[...] proces tworzenia nowej, innowacyjnej dla organizacji wiedzy spersonalizowanej, która następnie zostaje przekształcona w skodyfikowaną i niejednokrotnie ugruntowaną. W procesie tym wykorzystywane 
są między innymi metody heurystyczne. Innowacje produktowe kreowane są współcześnie głównie w ośrodkach badawczo-rozwojowych, ale cały szereg innowacji (np. procesowych) powstaje podczas codziennej praktyki, prac zespołów projektowych, kół jakości czy zespołów zadaniowych" (Mikuła 2006, s. 41).

\section{Selekcjonowanie wiedzy w mikroprzedsiębiorstwie}

Komentarz Meblarski może powstawać dzięki odpowiedzialnemu selekcjonowaniu wiedzy, czyli kolejnemu zadaniu operacyjnemu. W tym przypadku można się odwołać do definicji selekcji wiedzy: „Zgromadzone zbiory wiedzy muszą zostać poddane procesowi selekcji z punktu widzenia obszaru użyteczności. U podstaw selekcji powinny leżeć opracowane kryteria, za pomocą których dokonuje się klasyfikacji zgromadzonej wiedzy. Obszary użyteczności mogą być różnie dzielone, np. w przekroju funkcji (marketing, produkcja, finanse, personel itd.), czasu (wiedza o przeszłości, teraźniejszości, przyszłości), stopnia dostępności (wiedza ogólnie dostępna, o ograniczonym dostępie, tajemnica chroniona przez konkurentów), według szans i zagrożeń, dotycząca organizacji, bliższego i dalszego otoczenia" (Mikuła 2006, s. 41).

Usługa w postaci bezpłatnego Komentarza Meblarskiego oferowana przez „B+R Studio" to również dowód, że firmy na każdym rynku potrzebują stałego dostępu do informacji, która pozwala im na skutecznie funkcjonowanie i zapewni ciągły rozwój.

\section{„B+R Studio Analizy Rynku Meblarskiego" a skuteczny transfer wiedzy}

Mikroprzedsiębiorstwa - i inne organizacje - muszą ciągle poszukiwać, porzucając rutynę i pasywne zachowania ,,[... na rzecz stałego przeistaczania się (przedsiębiorczość wewnętrzna), nawet tworzenia się od nowa, aby wyprzedzać żądania, których jeszcze nie postawiono" (Penc 2002, s. 5).

W przypadku organizacji inteligentnej ważne miejsce obok kreowania wiedzy zajmuje również transfer wiedzy, stały proces uczenia się. Te własności organizacji inteligentnej pozwalają na stały rozwój. Uczenie się i kreowanie nowej użytecznej wiedzy pełni funkcję motywującą, co w przypadku mikroprzedsiębiorstwa inteligentnego ma znaczący wpływ na jego proces rozwoju. To właśnie pozyskiwana, kreowana i rozwijana w procesie uczenia się wiedza umożliwia przedsiębiorstwu zachowanie długotrwałej przewagi konkurencyjnej, która może być oparta tylko na specyficznych zasobach lub umiejętnościach organizacji, które przyczyniają się do rozwiązywania problemów istotnych dla klientów oraz są trudne do podrobienia lub substytuowania przez konkurencję (Raub, Buchel 1996, s. 26).

Na transfer wiedzy w organizacji składają się cztery subprocesy: pozyskiwanie wiedzy, udostępnianie wiedzy, rozpowszechnianie wiedzy, dzielenie się wiedzą.

1. „Pozyskiwanie wiedzy jest procesem przepływu wiedzy z otoczenia organizacji do jej wnętrza, jak i procesem, w trakcie którego pracownicy zdobywają wiedzę 
ze źródeł wewnętrznych, a więc od swoich współpracowników, z dokumentacji i baz danych, dostępnych książek i czasopism [...]. Nośnikiem wiedzy jest tu informacja.

2. Udostępnianie wiedzy jest procesem odwrotnym do pozyskiwania, w trakcie którego ludzie przekazują wiedzę swoim współpracownikom, podając im informację [...]. Udostępnianie wiedzy jest też procesem przepływu wiedzy od organizacji do jej otoczenia [...]. Organizacja udostępnia również swoją wiedzę poprzez fakt sprzedaży produktów i usług oraz realizację procesów, które mogą być obserwowane przez podmioty otoczenia.

3. Rozpowszechnianie wiedzy jest rozwiniętą formą udostępniania wiedzy, a różnica jest $w$ zasięgu udostępniania [...]. Rozpowszechnianie wiedzy jest zaś działaniem mającym na celu stworzenie $\mathrm{z}$ danego zasobu wiedzy ogólnie dostępnej [...].

4. Dzielenie się wiedzą to proces polegający na wzajemnym przekazywaniu sobie wiedzy przez ludzi w procesie komunikacji i podczas współpracy. Dzieleniu podlega wiedza spersonalizowana jawna i cicha. Podczas tego procesu ludzie mogą wspomagać się wiedzą skodyfikowaną (np. informacjami z dokumentacji organizacyjnej) i ugruntowaną (np. poprzez analizę uszkodzeń produktu)" (Mikuła 2006, s. 40).

„B+R Studio” aktywnie wykorzystuje każdy z subprocesów transferu wiedzy, zarówno w przypadku Komentarza Meblarskiego, jak i ogólnego funkcjonowania firmy.

\section{Organizacja inteligentna szansą na stały rozwój mikroprzedsiębiorstw}

„B+R Studio Analizy Rynku Meblarskiego” jest dowodem, że organizacja inteligentna nie ogranicza się do wielkości firmy, ale do jakości potencjału intelektualnego. Komentarz Meblarski jest najlepszym przykładem na wykorzystanie potencjału intelektualnego omawianej firmy oraz efektem sprawnego wykorzystania aktywów niematerialnych.

Aby Komentarz Meblarski był pożądanym źródłem wiedzy dla odbiorców, pracownicy „B+R Studio” nie pomijają fundamentalnego połączenia aktywów niematerialnych, których wynikiem jest kapitał intelektualny.

Samo uruchomienie przez firmę usługi Komentarz Meblarski przy braku podnoszenia jakości kapitału własnego nie dałoby oczekiwanych rezultatów i nie pozwoliłoby na:

- budowanie zaufania do przekazywanych informacji,

- budowanie wizerunku „B+R Studio” jako wiarygodnego źródła informacji o rynku meblarskim.

Należy podkreślić, że na sukces firmy, bez względu na jej wielkość, ma wpływ potencjał intelektualny. „Warunkiem skutecznego zarządzania informacją i wiedzą w organizacji jest możliwie jak najwyższy potencjał intelektualny. Oznacza to wysokie kwalifikacje formalne (poziom wykształcenia) możliwie najliczniejszej grupy pracowników” (Koźmiński, Jemielniak 2008, s. 265). „B+R Studio Analizy Rynku Meblarskiego", aby umieć sprostać zmieniającym się wymaganiom 
rynkowym, musi nieustannie się uczyć oraz stale podejmować wysiłek twórczy i wykorzystywać umiejętności kreatywne własnego zespołu specjalistów. Jest to konieczne, aby odnajdywać się $\mathrm{w}$ dynamicznym społeczeństwie informacyjnym i napędzać rynek pod względem zapotrzebowania na realizowane przez siebie profesjonalne usługi.

Organizacja inteligenta to taka, która potrafi skutecznie przewidzieć w przyszłości wymagania na etapie kształtujących się potrzeb rynku. Również firmy mikro muszą pamiętać, że konkurencyjność zapewnią „,[...] indywidualne charakterystyki osobnicze, takie jak posiadane doświadczenie i umiejętność jego wykorzystania, ciekawość intelektualna, wyrażająca się dążeniem do pozyskiwania nowych informacji i stałego wzbogacania posiadanego zasobu wiedzy, umiejętność prowadzenia debaty i konfrontowania ze sobą różnych informacji, punktów widzenia i rodzajów wiedzy" (Koźmiński, Jemielniak 2008, s. 265).

Organizacja inteligentna w swoim założeniu kładzie nacisk na nieustające uczenie się zaangażowanych pracowników, dzielenie się wiedzą i wspólne podejmowanie wysiłku $\mathrm{w}$ celu zachowania konkurencyjności na wciąż zmieniającym się rynku. „B+R Studio Analizy Rynku Meblarskiego” jest przykładem na to, że organizacja inteligentna nie jest wyłącznie zarezerwowana dla dużych firm. Ważne, aby mikroprzedsiębiorstwa permanentnie prowadziły proces specjalizacji i w ten sposób nabywały i utrzymywały swój profesjonalny charakter, za który odpowiedzialni są ich pracownicy.

\section{Literatura}

1. Grudzewski W.M., Hejduk I.K. (2002), Kreowanie systemów zarządzania wiedza podstawa dla osiagania przewagi konkurencyjnej współczesnych przedsiębiorstw, [w:] Grudzewski W.M., Hejduk I.K. (red.), Przedsiębiorstwo przyszłości - wizja strategiczna, Difin, Warszawa.

2. Koźmiński A.K., Jemielniak D. (2008), Zarządzanie od podstaw, Wydawnictwa Akademickie i Profesjonalne, Warszawa.

3. Mikuła B. (2005), Geneza, przesłanki i istota zarzadzania wiedza, [w:] Perechuda K. (red.), Zarzadzanie wiedza w przedsiębiorstwie, Wydawnictwo Naukowe PWN, Warszawa.

4. Mikuła B. (2006), Zadania organizacji w zakresie zarzadzania wiedza, „E-mentor” nr 5(17).

5. Morawski M. (2005), Organizacja inteligentna, [w:] Perechuda K. (red.), Zarzadzanie wiedza w przedsiębiorstwie, Wydawnictwo Naukowe PWN, Warszawa.

6. Nowa definicja MŚP. Poradnik dla użytkowników $i$ wzór oświadczenia, Wspólnoty Europejskie 2006.

7. Penc J. (2002), Zarzadzanie oparte na wiedzy, „Organizacja i Kierowanie”, nr 1.

8. Raub S., Buchel B. (1996), Organisationales Lernen und Unternehmenssrtategie «core capabillities» als Ziel und Resultat organisationalen Lernens, „Zeitschrift Fuhrung + Organisation", Nr 1.

9. Stosik A. (2005), Zarzadzanie wiedza i kapitatem intelektualnym w matych firmach, [w:] Perechuda K. (red.), Zarządzanie wiedzq w przedsiębiorstwie, Wydawnictwo Naukowe PWN, Warszawa. 


\title{
THE FUNCTIONING OF ORGANIZATION BASED \\ ON THE EXAMPLE OF MICROBUSINESS \\ “B+R STUDIO FURNITURE MARKET ANALYSIS"
}

\begin{abstract}
In this article a microbusiness is presented as an example of an intelligent organization, which in its daily practice, not only understands the concept of intellectual capital and knowledge management, but it also implements knowledge management strategies. " $\mathrm{B}+\mathrm{R}$ Studio Furniture Market Analysis" is given as an example of a microbusiness that provides the analysis of the furniture market. In December 2012 the business launched a free service - Furniture Comments. As a part of the service the team of employees share the tacit knowledge which recently has not been available to the public. Analysis is aimed is aimed at the furniture industry and related areas, which in order to enable other companies to the make right decisions, must have access to the knowledge and current information sources. The priority for every intelligent organisation should be sharing its knowledge with other companies, make effective decisions, must have access to knoeswledge and current information sources. In this article was presented that material goods in an open society are a priority.
\end{abstract}

Keywords: intelligent organisation, microbusiness, the knowledge transfer, intellectual capital, types of knowledge 